\title{
Peace, Sports Diplomacy and Corporate Social Responsibility: A case study of Football Club Barcelona Peace Tour 2013
}

\author{
Jordi de San Eugenio
}

Xavier Ginesta

Jordi Xifra

\begin{abstract}
The aim of this article is to analyse the initiative FC Barcelona Peace Tour 2013, in Israel and Palestine. This research is based on lengthy interviews with people associated with the initiative and the use of primary sources, both institutional and journalistic. Secondary sources have also been used, such as journalistic accounts of the initiative. The article thus examines the nature of FC Barcelona Peace Tour 2013, which it defines as an exercise in sports diplomacy, inspired by civil society and articulated through the club. The article concludes that FC Barcelona has been able to act as a mediator between two opposed communities due to the universal values linked to its brand and its nature as a "civic religion". This notwithstanding, the political problems that arose during the planning of the initiative highlight the geopolitical complexity of the Middle East and, by extension, the limits of sports diplomacy.
\end{abstract}

Keywords: Israel; Palestine; Peace-keeping; Sports diplomacy; Football Club Barcelona.

Subject classification codes: include these here if the journal requires them

\section{Introduction}

Sport has often functioned as a neutral space within divided societies, with great impact among the young. ${ }^{1}$ In this sense, there are numerous precedents which demonstrate the capacity of sport to promote peace in conflict-ridden regions, that is, the possibility for sport to play an important role in peace-keeping programmes. ${ }^{2}$ 
One of the most notable initiatives relating to the role of sport in intervening and mediating in divided societies is Football for Peace (F4P), a project initiated in 2001 to promote the culture of sport in Israel ${ }^{3}$ under the auspices of the World Sport Peace Project (WSP) and with the participation of six volunteer coaches and a group leader from the University of Brighton. Many authors have defined this project as essential to the promotion of grass-roots level sport in Israel and to fostering coexistence and improved inter-group relations across differentiated groups and divided societies. ${ }^{4}$

With regard to the strategy of FC Barcelona, the club continues to seek out links to the international community within the framework of a marketing and corporate social responsibility policy which has been given a significant boost in recent years, especially following the restructuring of the FC Barcelona Foundation during the presidency of Joan Laporta (2003-2010) and its adhesion to the Millennium Development Goals of the United Nations in $2006 .{ }^{5}$ More recently, FC Barcelona has joined the board of the public-private body of the Public Diplomacy Council of Catalonia (Diplocat), which makes the club a formal actor within the Catalonian government's paradiplomacy framework (A. Royo, personal interview, 13/12/2013).

Whether through the establishment of relations of a humanitarian or paradiplomatic nature, the club aims to be active in the reconfiguration that global geopolitical actors are undergoing in the twenty-first century. ${ }^{6}$ As the consulting firm Sport+Markt notes, Barça have 50 million fans in Europe alone ${ }^{7}$, and it is thus able to take advantage of its immense global prestige and following. Furthermore, a study by Francesc Pujol and Quique Gallemí from the University of Navarra asserts that the Barça brand is the most powerful of all sports brands. ${ }^{8}$ In summary, the club participates actively in the "global media-sport complex", which, in sociological terms, should be understood as a "combination of all organizations, processes, texts and products that 
form the culture of modern sport and establish it as a socio-cultural institution closely connected to the politics of everyday life". ${ }^{10}$

On analysing the importance of FC Barcelona in cultural terms, Professor Jordi Xifra examines its "religious dimension", that is, the way the club constitutes a civil religion in that it "synthesizes a panoply of meanings that have snowballed in the club's century-old history and in the history of the imagined community that is Catalonia" ${ }^{\prime 2}$. In a similar vein, Salvador offers an interpretation in which fans do not only follow the club's sporting successes but, in addition, "they attribute transcendental meanings and truths" to the club. ${ }^{13}$ As Xifra further observes:

"For a multitude of people all of the ritual devices that spring up around the club transcend the merely sporting ('more than a club') to become both a show of sport and a wealth of ethnic-national ritual devices geared towards creating and binding together a national community that is crying out for social cohesion by virtue of its historical fragility, as the Catalan community."

With all the above in mind, the objective of this article is to analyse how the FC Barcelona Peace Tour 2013 in Israel and Palestine can be interpreted as an act of sports diplomacy ${ }^{15}$, taking advantage of the symbolic value that FC Barcelona carries for both of the opposed communities in this region of the Middle East: Israelis and Palestinians, Jews and Muslims. This, it should be noted, is a field of study, which has received little attention within the theoretical and applied studies on traditional diplomacy. ${ }^{16}$ The initiative led by FC Barcelona aims, among other objectives, to use sport (in which it is a global leader) and sports events to strengthen and project its brand image globally through explicitly taking on a commitment to peace, freedom and democracy, which are values inherent to the club and which have always formed part of its brand ${ }^{17}$. In practice, this line of action was witnessed back in 2005 as, under the auspices of Ernest 
Lluch Foundation and the businessman Lluís Bassat -advertising and PR expert and leading light of the Catalonian Jewish community- FC Barcelona organised a 'match for peace' against a Palestinian-Israeli team at the Camp Nou stadium. ${ }^{18}$

\section{The Israel-Palestine conflict and the value of sport in a process of peace and reconciliation}

The Israel-Palestine conflict is complex and has multiple causes and manifestations. ${ }^{19}$ Smith traces the origins of the conflict back to 1516, in the context of the Ottoman Empire, but also focusing the attention to the birth of Zionism in the nineteeth century. ${ }^{20}$ This confrontation has persisted until the twenty-first century, as seen in the attempted peace negotiations at Camp David, Palestinian rebellion and political resistance (2006), as well as in Israeli unilateralism (1999-2009) (X. Mas de Xaxas, personal interview, 23/1/2014). The conflict, which is ongoing and which has international repercussions, appears to have no end in sight. Many authors, such as Gelvin, Dowty, Halper, Morris or Mullin ${ }^{21}$ agree that there are four critical factors which have determined the historic confrontation between Israelis and Palestinians: territory (Israel's occupation of Palestinian lands); history and colonialism (the creation of the Jewish State on 14 May 1948); ethnic and religious factors (coexistence between Jews, Muslims and Christians); and, finally, disputes over natural resources (principally water).

The value of sport in peace and reconciliation processes has been established and clearly systemised by Sugden ${ }^{22}$, who develops an interpretive model known as the 'ripple effect', which shows the circumstances under which sport can contribute significant added value in the promotion of social justice and human rights in deeply divided societies. As Sugden contends: 
"Peace is only possible when significant proportions of ordinary people are ready for and open to conflict resolution. By way of illustration, politicians may be in the driving seat but for the peace bus to get anywhere meaningful along its road map there must be passengers willing to climb on board. This comes gradually through social and cultural engagement in everyday life". ${ }^{23}$

In this line, this author outlines a model for action based on concentric circles which ripple out, with the central space occupied by actions carried out by children "from different stakeholder communities, surrounded by adult volunteer coaches and significant other (relatives, teachers, community leaders, etc.) from the local communities, and the international volunteers". ${ }^{24}$ Sugden contends that "the nature of the structure, organization, management and delivery of activities and encounters taking place within these two circles is crucial in determining the outcome of any such sport intervention. ${ }^{, 25}$ In the outer circles we find institutional actors, "through whom ideas and findings emanating from the project can be articulated within the wider policy community for sport". ${ }^{26}$

Sugden cites the examples of South Africa (before and after Apartheid), Northern Ireland and Israel to illustrate the impact of sport in working for peace in conflicted societies. In relation to Israel and football, journalist Ramon Usall provides a thorough analysis of various episodes of the country's sporting history. ${ }^{27}$ One example of this was the cup success of Bnei Sakhnin in 2004, this being a modest club from the Arab-majority town of Sakhnin which included Muslim, Jewish and Christian players. Both the club's Jewish owner (Arkady Gaidamak) and Muslim captain (Abbas Suan) stressed that the club's victory “contributed to peace and harmony amongst the people of Israel due to it being a team made up of players from different origins and religions". 28 
In fact, there are numerous cases of sports mediation in the Israel-Palestine conflict, especially in global events such as the Olympic Games or world championships. ${ }^{29}$ However, one of the sports activities, which has done most to mediate for peace and reconciliation amongst the young, especially in Israel, is the above mentioned initiative of Football for Peace (F4P).

In terms of this article, Football for Peace (F4P) is of particular interest, as the presence of FC Barcelona in Israel and Palestine represents a continuation - albeit at a different level - of the concept and philosophy of the F4P initiative, which has frequently been dubbed as ephemeral and utopian. ${ }^{30}$ Therefore, the project developed by FC Barcelona (Peace Tour 2013) fits in with the ideological context of Football for Peace through the way in which it reinforces its key aims (peace and democracy) as well as helping to project its values internationally.

\section{Public diplomacy, cultural diplomacy and sports diplomacy}

Public diplomacy represents the natural evolution of traditional or State diplomacy towards the establishment of a new form of international relations, this being based on co-participation between governments and civil society. Manuel Castells defines public diplomacy in the following terms:

"Public diplomacy is not propaganda. And it is not government diplomacy. We do not need to utilise a new concept to define traditional practices of diplomacy. Public diplomacy is diplomacy of public opinion, that is, the projection of the values and ideas of the public onto the international sphere." 31

In this line, Nichollas J. Cull locates the origin of the concept in the mid-1960s:

"The term public diplomacy is new. It was first applied in 1965 to the process by which international actors seek to accomplish the goals of their foreign policy by 
engaging with foreign publics and has gained international currency only since the end of the cold war." 32

For Cull, sports diplomacy forms an element of cultural diplomacy, falling within the more general framework of public diplomacy, which goes beyond traditional government diplomacy. In this vein, using the case study of the FIFA World Cup held in South Africa in 2010, Ndlovu ${ }^{33}$ offers further evidence regarding the contribution of football to a country's international positioning strategy in terms of cultural diplomacy and foreign policy. And Chehabi traces the origins of sports diplomacy back to the World Table Tennis Championships held in Japan in 1971, when 'ping pong diplomacy' was deployed with the invitation of the US team to China, which included an official visit by US President Richard Nixon. ${ }^{34}$ Finally, Murray summarises sports diplomacy in the following terms:

"It involves representative and diplomatic activities undertaken by sports people on behalf of and in conjunction with their governments. The practice is facilitated by traditional diplomacy and uses sports people and sporting events to engage, inform and create a favourable image among foreign publics and organisations, to shape their perceptions in a way that is (more) conducive to the sending government's foreign policy goals." ${ }^{, 35}$

In terms of the definitions advanced by Castells, Cull and Murray, we contend that the initiative Football Club Barcelona Peace Tour 2013 has public diplomacy connotations in that it constitutes a diplomatic exercise aimed at the international projection of values linked to football as a symbol of peace. ${ }^{36}$ In this line, the role played by the players of Barça can be interpreted as that of "messengers of peace"37. Thus, when the actor and driving force behind this type of initiative is a sports club, and the main argument is "sport makes us all equal and leads us towards peace"38, we can begin to talk of sports diplomacy, as we see the value of sport as a pacifying force. In 
the case of the FC Barcelona Peace Tour this was manifested in the sharing and projection of the values of a global football club, which supports freedom and democracy. ${ }^{39}$

Beyond the corporate social responsibility activities that any elite sports organisation is compelled to carry out, in Israel and Palestine FC Barcelona was "everybody's club", functioning as a banner for peace and freedom in a region of conflict. In Palestine, amongst those who turned up to watch the players in Dura, comments were made along the lines of "FC Barcelona is the team of the poor". (X. Mas de Xaxas, personal interview, 23/1/2014). Therefore, by extolling these values, the club strengthens its image on an international scale, as well as bolstering its leitmotif of being "more than a club". Through sports diplomacy, the diplomatic capacity of the club was demonstrated by the opening of a modest channel of dialogue, "a bridge between Israel and Palestine built on the basis of football and childhood". (X. Mas de Xaxas, personal interview, 23/1/2014). As the leader of the Palestinian National Authority (PNA), Mahmoud Abbas, stated, "If Leo Messi helps me to make peace with the Israelis, then he's very welcome”. (X. Mas de Xaxas, personal interview, 23/1/2014).

\section{Methodology}

The analysis of the initiative Football Club Barcelona Peace Tour 2013 has been carried out through a process of articulated documentation, using both primary and secondary sources. In terms of primary sources, information has been obtained from FC Barcelona's press office and communications department.40 In addition, two lengthy interviews were conducted with professionals who have worked with FC Barcelona in the field of sports diplomacy. These were Xavier Mas de Xaxàs - former correspondent 
for La Vanguarida in Israel and ideologue of the initiative under analysis in this article, and the secretary general of Diplocat, Albert Royo. As Mas de Xaxàs notes:

\begin{abstract}
"I spent three years covering the Arab Spring for the newspaper La Vanguardia and I realised that FC Barcelona was the most widely supported club in this part of the world. Then, taking advantage of my personal relationship with the vice-president of FC Barcelona, Javier Faus, I mentioned the possibility of using Barça as a diplomatic actor in Israel” (X. Mas de Xaxàs, personal interview, 23/1/2014).
\end{abstract}

With respect to secondary sources, after reviewing the scientific literature most relevant to this case, we have carried out a discursive analysis of journalistic sources ${ }^{41}$ linked to the Catalonian club's tour of Israel and Palestine. All the published articles related to the tour between August 2 and 5 have been analysed (informative, interpretive and op-ed pieces) from the principal Catalonian newspapers (La Vanguardia, El Periódico, El Punt Avui, Ara, El 9 Esportiu, El Mundo Deportivo and Sport) and Spanish newspapers (Marca, AS, El País, Abc and La Razón). In total there were 78 published articles, from which we have extracted the excerpts, which best illustrate the concept of sports diplomacy as applied to this research work.

\title{
A case study of Football Club Barcelona Peace Tour 2013: corporate social responsibility and beyond
}

The arrival of Joan Laporta as president of FC Barcelona in 2003 brought with it a radical change in the club's marketing policy and an explicit commitment to societal goals. ${ }^{42}$ In general terms, there was a professionalisation process of the club's human resources and logistics in order to generate a more solid corporate reputation, which would be articulated through the global projection of the humanitarian (or universal) values associated with the club. ${ }^{43}$ The renewed commitment to corporate social responsibility brought in by Laporta reached an important moment in 2006, when a non- 
profit sponsorship deal was signed with UNICEF (United Nations Children's Fund), which involved the club's shirt bearing a sponsor's name for the first time in its history.

Laporta's strategy of promoting non-profit social projects was continued to a certain degree by his successor, Sandro Rosell (2010-2014), although UNICEF was replaced as the main shirt-sponsor by the Qatar Foundation following the signing of an agreement with Qatar Sports Investment (QSI) on 13 December 2010, which would channel 165 million euros to FC Barcelona over six seasons. ${ }^{44}$ Following this line, in recent years the club's foundation has set up numerous projects which are clearly committed to equal opportunities, human rights, freedom and democracy. ${ }^{45}$

For quite some time Barça has been working for peace between Israel and Palestine, ${ }^{46}$ "where $80 \%$ of the population of both territories feels a deep connection with and admiration for the club". ${ }^{47}$ The Football Club Barcelona Peace Tour 2013 took place in Palestine and Israel on August $3 \& 4$ and was covered by 450 national and international journalists. ${ }^{48}$ Furthermore, Al-Jazzera -which has bought the broadcasting rights to the BBVA Spanish Football League for the Middle East, and which has a good relationship with FC Barcelona owing to the contract with QSI $^{49}$ - was the principal television broadcaster of this event throughout the region. ${ }^{50}$ And this is where we see the strength that the Barça brand carries in focusing the attention of the media and, in consequence, the capacity of the club to act proactively in the projection of a message of conciliation between "two communities which, due to demonization, have forgotten that they can also share" ${ }^{, 51}$. In this vein, Nichollas J. Cull notes the important role played by international news broadcasting as part of "an actor's attempt to manage the international environment by using the technologies of radio, television, and the Internet to engage with foreign publics". 52 
Both in Palestine and Israel, in his institutional statements, the club's president at the time, Sandro Rosell, ${ }^{53}$ explained the objectives that FC Barcelona aimed to achieve through its visit to the Middle East:

"We have come to these territories to strengthen our bonds of friendship and to help you, Israelis and Palestinians, to identify points of contact which help you along the road to peace. We do this with great humility but with the conviction that Barça is one of the things that you have in common, as we have been told that we are the most popular foreign team in Israel and Palestine. This fills us with pride and, at the same time, legitimises and encourages us to help you achieve this objective".

The club's contribution in the Middle East was made through two special coaching sessions (football clinics) and open-door training sessions, one in Dura and the other in Tel Aviv, with support from the sports events company Comtec.

The initial idea had been for FC Barcelona to take advantage of its pre-season tour of Asia to stop off and play a match in the Middle East against a combined Palestine-Israel team. Negotiations between the club, the Israeli government and the PNA started with an initial visit in February 2013, which was set up by two La Vanguardia journalists, Xavier Mas de Xaxas and Henrique Cymerman. As Mas de Xaxás noted:

\footnotetext{
"Although presidents Shimon Peres and Mahmoud Abbas initially viewed this positively, the project ran into many difficulties. On the one hand the Israeli extreme right put strong pressure on the government of prime minister Benjamin Netanyahu and, on the other, the Palestinians also demanded concessions from Israel related to recognition for their national team and Olympic committee.$^{54}[\ldots]$ Taking into consideration that the club was caught in the middle of a negotiation which was completely political, and that it had to plan its pre-season arrangements, the initial idea was cancelled" (X. Mas de Xaxas, personal interview, 23/1/2014).
} 
In addition, the trip coincided with the resumption of peace talks in Washington between the two parties. However, taking advantage of the contacts that had already been established, alternative plans were made for the club's stay in the region, with there being no sponsor in order not to "commercialise or politicise the visit, which meant a cost of 500,000 euros for the club" (X. Mas de Xaxas, personal interview, 23/1/2014). In Palestine, on August 3, the Barça team held a training session in the Dura Stadium, near Hebron, in front of 25,000 spectators. ${ }^{55}$ Later, at the same stadium, a special coaching session was held with 40 boys and girls between 8 and 12 years old who had been selected by the Palestinian Football Academy. FC Barcelona president Sandro Rosell was received in the Muqata -the headquarters of the PNA- by Palestine's highest representative, Mahmoud Abbas, and by the head of the Palestinian Football Association, General Jibril Rajub. Abbas praised the role of FC Barcelona within his country as a "dynamising agent of a people". 56

In Israel, on August 4 Barça visited the Wailing Wall in Jerusalem and held a training session at the Bloomfield Stadium in Yafo (Tel Aviv) in front of 14,400 spectators, all children. ${ }^{57}$ Forty Israeli and Palestinian children, as well as some disabled children, took part in the special coaching session. The children came from two clubs which are historically opposed for religious and political reasons: Beitar Jerusalem and Bnei Sakhnin ${ }^{58}$. The reactions of the Palestinian adolescents who attended Bloomfield Stadium illustrate the success of the initiative. As the special correspondent of the newspaper El Periódico de Catalunya in Yafo reported:

\footnotetext{
“'Football can contribute to bringing Palestinians and Israelis together,' according to Nazir Abu Akir, an 18 year-old from Hebron. This was one of the aims of Barça with the organisation of this visit, which has been named as the Peace Tour. 'Today, with Barça, we forget about the Israeli occupation and only think about football,' declared 16 year-old Ibrahim Darwish". 59
} 
The club and its directors were received by Shimon Peres, the president of the State of Israel, and by the Prime Minister, Benjamin Netanyahu, who, despite the noncommercial aspect of the tour, referred to the positive impact that the visit of FC Barcelona could have in boosting Israel as a tourist destination. The journalist Joan Doménech picked up on this, noting:

\footnotetext{
"The Israeli leader, leaving aside institutional roles, explained that his main wish was to see good matches, achieve peace and security, and that $1 \%$ of the 300 million Barça fans visit his country one day". 60
}

It was in fact the case that the visit of FC Barcelona did not only involve a bridge between Israel and Palestine, but also facilitated a meeting between two figures from the Israeli political scene who were at odds with one another: the president and his prime minister.

\footnotetext{
"We organised the visits on equal terms. In Palestine Rosell was received by Abbas, and in Israel both Peres and Netanyahu wanted to host Rosell in their respective official residences. As no agreement was reached between them, the club took a firm line and invited them both to the hotel where they were based. The prime minister then immediately agreed to go to Shimon Peres' reception at the president's residence of Beit Hanasí" (X. Mas de Xaxas, personal interview, 23/1/2014).
}

Although not mentioned by the reports that were published, apart from Peres and Netanyahu, FC Barcelona had an important ally in Israel in Yair Lapid, leader of the centrist party Yes Atid, which forms part of the coalition government. Lapid was a journalist before becoming a politician and is a personal friend of La Vanguardia correspondent Henrique Cymerman. In February of 2013 he played a central role in getting the support of Netanyahu. It was thereby possible to take advantage of the fact that Yes Atid controls the ministry of Education. In these terms, Mas de Xaxas notes: 
"The visit of FC Barcelona was promoted as an educational event and was used to launch the anti-racism programme I am the Other and to fill Bloomfield Stadium with children from schools across Israel, with buses laid on from every corner of the country" (X. Mas de Xaxas, personal interview, 23/1/2014).

\section{Conclusion}

The initiative Football Club Barcelona Peace Tour 2013 reinforces the symbolic values of football understood as a universal language for peace. These values are inspired by the framework of Football for Peace (F4P), an initiative which was at one time slated as being irrelevant and unsustainable in the long term in Israel ${ }^{61}$, and whose usefulness and importance have been boosted by initiatives such as that carried out by FC Barcelona.

Furthermore, Barça's visit to Israel illustrates the contribution that sport can make to human rights, equal opportunities and a spirit of democracy, peace and reconciliation in historically divided societies. This represents a clear representation of the "ripple effect" advanced by Sugden ${ }^{62}$, who, in the ambit of sport, uses policies of reconciliation through children as the base of his model. Indeed, the Peace Tour 2013 was conceived as a programme which was primarily focused on strengthening the bonds of friendship between Jewish and Muslim adolescents. The quotes of some of the participants taken from the press reports of the tour are testimony to this, as is the symbolic value placed on the initiative by the Israeli Ministry of Education, which is led by the centrist party Yes Atid.

From the club's perspective, this initiative reinforces its brand image, and it goes beyond being an exercise of corporate social responsibility. As has been set out throughout the article, the event can be considered as an exercise in cultural and media diplomacy -with 450 accredited journalists- in the ambit of sport ${ }^{63}$, in which a football club can carry out the diplomatic functions traditionally pertaining to a State, acting as 
an historic intermediary in a conflict with international connotations.

However, as Mas de Xaxes observes, "the process of negotiation has allowed FC Barcelona to see that peace between Israel and Palestine is almost impossible, and that the only practical approach is to maintain the current status quo, which does not satisfy the Palestinians" (X. Mas de Xaxàs, personal interview, 23/1/2014). This notwithstanding, the arguments that were used to justify the tour reinforce the club's historic motto of being "more than a club" and, in this line, the initiative boosts the club's position within the "global media sports complex". 64

Through this initiative, FC Barcelona thus demonstrates its ability to exercise international influence, articulated through a peace tour with the capacity to mobilise two historically divided peoples and to find agreement between two opposing politicians, the Israelis Shimon Peres and Benjamín Netanyahu. The club thereby not only reinforces the value of peace amongst its corporate attributes but also sets itself up as firm civic ambassador from the field of sport ${ }^{65}$, constituting itself as an actor which is legitimated by civil society. This is illustrated by the fact that, following the tour, the Israeli Ministry of Education started a programme through which the football teams from Israeli state schools train with the Barça corporate values:

\footnotetext{
"The club has committed itself to passing on know-how through coaches, in exchange for which kids will play with the values of Barça as an institution as part of the programme FutbolNet,66 which is run by the FC Barcelona Foundation" (X. Mas de Xaxàs, personal interview, 23/1/2014).
}

In fact, although the initiative Football Club Barcelona Peace Tour 2013 was devised from civil society -by two journalists who are experts in the Middle East-it is notable that it is the club's foundation, which is responsible for the club's corporate social responsibility project, which manages the follow-up processes related to the tour. 
To conclude, in the context set out, Barça functions as a universal, civil religión ${ }^{67}$, insofar as it recieves popular devotion from the Palestinian and Israeli people. The club is thus constituted as a common denominator or element of shared heritage within a public ritual which is transformed into an act of faith, from which attempts are made to create bonds of peace in the Middle East. Barça is the club of everyone, "the club of the poor", promoting shared peace through sport as a symbol which joins two communities. The journalist Germà Capdevila illustrates this graphically within the context of this article, stating that "to paraphrase the military historian Karl von Clausewitz, sport is politics by other means". ${ }^{6}$

\section{References}

Aguilar, F. 2013. "Más que dos “clínics"”. Mundo Deportivo, August 4, 4.

Alba, A. 2013. “Huella en Tierra Santa”. El Periódico de Catalunya, August 5, 16.

Badia J. Josep Suñol i Garriga. Viure i morir per Catalunya. Lleida: Pagès Editors, 2011.

Bassas, A. 2013. “Un design al Mur de les Lamentacions”. Ara, August 5, 33.

Cabré M. 2013. “Dues jornades blaugrana per contribuir a la pau”. El Punt Avui, August 3,36 .

Capdevila, G. 2013. “Guerra i pau”. El 9 Esportiu, August 5, 3.

Cárdenas, A. Exploring the Use of Sports for Peacebuilding and Conflict Resolution. Liverpool: Archbishop Desmond Tutu Centre for War and Peace Studies and Liverpool Hope University, 2012. 
Castells M. “The new public sphere: Global civil society, communication networks, and global governance". The Annals of the American Academy of Political and Social Science 616, no.1 (2008): 78-93.

Castells M. Comunicación y poder. Madrid: Alianza, 2009.

Chadwick, S. and D. Arthur. "Més que un club (more than a club): the commercial development of FC Barcelona”. In International Cases in the Business of Sport, edited by S. Chadwick and D. Arthur, 1-12. Oxford: Elsevier, 2007.

Chehabi, H.E. "Sport Diplomacy between the United States and Iran". Diplomacy \& Statecraft 12, no 1 (2001): 89-106.

Correas, F. 2013. "10 milions pels amistosos de pretemporada”. El 9 Esportiu, August 4,6 .

Cull, N.J. "Public Diplomacy: Taxonomies and Histories". The Annals of the American Academy of Political and Social Science 616, no 1 (2008): 31-54.

Domènech, J. 2013. "Barça de paz”. El Periódico de Catalunya, August 5, 16.

Donnelly, P., M. Atkinson, S. Boyle and C. Szto. "Sport for development and peace: A public sociology perspective”. Third World Quarterly 32, no 3 (2011): 589-601.

Dowty, A. "Despair is not enough: Violence, attitudinal change, and 'Ripeness' in the Israeli-Palestinian conflict”. Cooperation and Conflict 41, no 1 (2006): 5-29.

EFE. 2011. "Messi and Barça, the Most media-conscious in the world". Sport, August 18. http://www.sport.es 
Gelvin, J.L. The Israel-Palestine Conflict: One Hundred Years of War. Cambridge: Cambridge University Press, 2005.

Gil-Lafuente, J. "Marketing management in a socially complex club: Barcelona FC". In Marketing \& Football: An international perspective, edited by M. Desbordes and S. Chadwick, 186-207. Oxford: Elsevier, 2007.

Ginesta, X. and E. Ordeix. "El fútbol profesional y su responsabilidad social corporative en Cataluña (2006-2010). Mucho más que Unicef”. Contratexto 20 (2012): 177-194.

Ginesta, X. and J. de San Eugenio. "The Use of Football as a Country Branding Strategy. Case Study: Qatar and the Catalan Sports Press". Communication \& Sport. Epub ahead of print 25 April 2013. DOI: 10.1177/2167479513486886.

Giulianotti, R. "Sport, peacemaking and conflict resolution: A contextual analysis and modelling of the sport, development and peace sector". Ethnic and Racial Studies 34, no 2 (2011): 207-228.

Halper, J. An Israeli in Palestine: Resisting Dispossession, Redeeming Israel. London: Pluto Press, 2008.

Hamil, S., G. Walters, and L. Watson. "The model of governance at FC Barcelona: Balancing member democracy, commercial strategy, corporate social responsibility and sporting performance". Soccer \& Society 11, no 4 (2010): 475-504.

Lea-Howarth, J. "Sport and conflict: Is football an appropriate tool to utilize in conflict resolution, reconciliation or reconstruction?" MA Dissertation. University of Sussex, 2006. 
Lieberfeld, D. "Promoting tractability in South Africa and Israel/Palestine: The role of semiofficial meetings". American Behavioral Scientist 50, no 11 (2007): 1542-1562.

Merkel, U. "The politics of Sport Diplomacy and Reunification in Divided Korea. One nation, Two countries and Three flags". International Review for the Sociology of Sport 43, no 3 (2008): 289-311.

Miguel, J. 2013. “El Barça convierte su 'clínic' en Palestina en un gesto por la paz”. Sport, August 4, 14.

Morris, B. One State, Two States: Resolving the Israel/Palestine conflict. New Haven, CT: Yale University Press, 2009.

Mullin, C. "Islamist challenges to the 'Liberal peace' discourse: The case of Hamas and the Israel-Palestine 'Peace process"'. Millennium - Journal of International Studies 39, no 2 (2010): 525-546.

Murray, S. "The two halves of sports-diplomacy". Diplomacy \& Statecraft 23, no 3 (2012): 576-592.

Murray, S. "Moving beyond the Ping-Pong table: Sports Diplomacy in the Modern Diplomatic Environment”. Public Diplomacy Magazine Winter (2013): 11-16.

Ndlovu, S.M. "Sports as cultural diplomacy: The 2010 FIFA world cup in South Africa’s foreign policy”. Soccer \& Society 11, no 1-2 (2010): 144-153.

Perearnau, F. 2013. "Barça sin fronteras”. Mundo Deportivo, August 4, 2.

Perearnau, F. 2013. "En casa de Mahmoud Abbas". Mundo Deportivo, August 4, 4. 
Perearnau, F. 2013. "Segundo paso hacia el 'Partido por la Paz"”. Mundo Deportivo, August 4, 8 .

Rookwood, J. and C. Palmer. "Invasion games in war-torn nations: Can football help to build peace?” Soccer \& Society 12, no 2 (2011): 184-200.

Rosell, S. "A global club that is proud of its identity". Catalan International View. A European Review of the World 14 (2013): 24-27.

Rowe, D. "Sport and the Reproduction of the Global". International Review of the Sociology of Sport 38, no 3 (2003): 281-294.

Rowe, D. "The Stuff of Dreams, or the Dream Stuffed? Rugby League, Media Empires, Sex Scandals and Global Plays". Paper presented at the $8^{\text {th }}$ Annual Tom Brock Annual Lecture, New South Wales Leagues' Club, September 21, 2006.

Salvador, J. Futbol, metàfora d'una guerra freda: Un estudi antropològic del Barça. Barcelona: Proa, 2004.

Schulenkorf, N. and J. Sugden. "Sport for Development and Peace in Divided Societies: Cooperating for Inter-Community Empowerment in Israel”. European Journal for Sport and Society 8, no 4 (2011): 235-256.

Shobe, H. "Place, identity and football: Catalonia, Catalanisme and Football Club Barcelona, 1899-1975”. National Identities 10, no 3 (2008): 329-343.

Smith, C. D. Palestine and the Arab-Israeli Conflict: A History with Documents. Boston: Bedford/St. Martin’s, 2010. 
Sugden, J. "Teaching and playing sport for conflict resolution and co-existence in Israel”. International Review for the Sociology of Sport 41, no 2 (2006): 221-240.

Sugden, J. "Anyone for football for peace? The challenges of using sport in the service of co-existence in Israel”. Soccer \& Society 9, no 3 (2008): 405-415.

Sugden, J. "Critical left-realism and sport interventions in divided societies". International Review for the Sociology of Sport 45, no 3 (2010): 258-272.

Sugden, J. and A. Bairner (eds). Sport in Divided Societies. Aachen: Meyer and Meyer, 2000.

Sugden, J. and J. Wallis. Football for Peace? The Challenge of Using Sport for Coexistence in Israel. Aachen: Meyer and Meyer, 2007.

Usall, R. Futbol per la llibertat. Lleida: Pagès Editors, 2011.

Whitfield, G. Amity in the Middle East. Brighton: The Alpha Press, 2006.

Xifra, J. "Soccer, civil religion, and public relations: Devotional-promotional communication and Barcelona Football Club". Public Relations Review 34, no 2 (2008): 192-198.

Yiftachel, O. Ethnocracy: land and identity politics in Israel/Palestine. Philadelphia, PA: University of Pennsylvania Press, 2006.

\footnotetext{
${ }^{1}$ See Sugden and Bairner (eds), Sport in Divided Societies; Sugden, "Anyone for football for peace?", 405-415; Schulenkorf and Sugden, "Sport for Development and Peace in Divided Societies", 235-256.

${ }^{2}$ See Lea-Howarth, "Sport and conflict"; Merkel, "The politics of Sport Diplomacy and Reunification in Divided Korea", 289-311; Sugden, "Critical left-realism and sport interventions in divided societies", 258-272; Rookwood and Palmer, "Invasion games in wartorn nations", 184-200; Donnelly, Atkinson, Boyle and Szto. "Sport for development and peace", 589-601; Cárdenas, Exploring the Use of Sports for Peacebuilding and Conflict Resolution.
} 
${ }^{3}$ See Whitfield, Amity in the Middle East.

${ }^{4}$ Sugden, "Teaching and playing sport for conflict resolution and co-existence in Israel", 226; Schulenkorf and Sugden, "Sport for Development and Peace in Divided Societies", 238.

${ }^{5}$ Ginesta and Ordeix. "El fútbol profesional y su responsabilidad social corporativa en Cataluña (2006-2010)", 186. See also Gil-Lafuente, "Marketing management in a socially complex club: Barcelona FC", 186-207; Xifra, "Soccer, civil religion, and public relations", 192-198.

${ }^{6}$ Castells, Comunicación y poder.

${ }^{7}$ Ginesta and San Eugenio, "The Use of Football as a Country Branding Strategy", 2.

${ }^{8}$ EFE. 2011. "Messi and Barça, the Most media-conscious in the world". Sport, August 18. http://www.sport.es

${ }^{9}$ See Rowe, "Sport and the Reproduction of the Global", 281-294; Rowe, "The Stuff of Dreams, or the Dream Stuffed?".

${ }^{10}$ Rowe, "The Stuff of Dreams, or the Dream Stuffed?", 3.

${ }^{11}$ Xifra, "Soccer, civil religion, and public relations", 192-198.

${ }^{12}$ Ibid., 194

${ }^{13}$ Salvador, Futbol, metàfora d'una guerra freda, 380.

${ }^{14}$ Xifra, "Soccer, civil religion, and public relations", 195.

${ }^{15}$ Murray, "The two halves of sports-diplomacy", 576. For an illustration of the concept of sports diplomacy, the State Department of the United States Government operates an interesting sports diplomacy initiative through its Bureau of Educational and Cultural Affairs. For information on this, visit: http://eca.state.gov/programs-initiatives/sports-diplomacy

${ }^{16}$ Cull, "Public Diplomacy: Taxonomies and Histories", 31-54.

${ }^{17}$ Badia, Josep Suñol i Garriga.

${ }^{18}$ Aguilar, F. 2013. "Más que dos “clínics"”. Mundo Deportivo, August 4, 4.

${ }^{19}$ Sugden, "Teaching and playing sport for conflict resolution and co-existence in Israel", 221.

${ }^{20}$ Smith, Palestine and the Arab-Israeli Conflict.

${ }^{21}$ See Gelvin, The Israel-Palestine Conflict; Dowty, "Despair is not enough", 5-29; Halper, An Israeli in Palestine; Morris, One State, Two States; Mullin, "Islamist challenges to the 'Liberal peace' discourse", 525-546.

${ }^{22}$ Sugden, "Critical left-realism and sport interventions in divided societies", 268-269.

${ }^{23}$ Ibid., 268.

${ }^{24}$ Ibid., 269.

${ }^{25}$ Ibid., 269.

${ }^{26}$ Ibid., 269.

${ }^{27}$ Usall, Futbol per la llibertat.

${ }^{28}$ Ibid., 158.

${ }^{29}$ Giulianotti, "Sport, peacemaking and conflict resolution", 207-228.

${ }^{30}$ Sugden, "Teaching and playing sport for conflict resolution and co-existence in Israel", 237238.

${ }^{31}$ Castells, "The new public sphere", 91.

${ }^{32}$ Cull, "Public Diplomacy: Taxonomies and Histories", 31.

${ }^{33}$ Ndlovu, "Sports as cultural diplomacy", 144-153.

${ }^{34}$ Chehabi, "Sport Diplomacy between the United States and Iran", 100-101.

${ }^{35}$ Murray, "The two halves of sports-diplomacy", 576.

${ }^{36}$ See Castells, "The new public sphere", 91; Cull, "Public Diplomacy: Taxonomies and Histories", 31; Murray, "The two halves of sports-diplomacy", 576.

${ }^{37}$ Bassas, A. 2013. "Un design al Mur de les Lamentacions". Ara, August 5, 33.

${ }^{38}$ Rosell, "A global club that is proud of its identity", 24-27.

${ }^{39}$ Murray, "Moving beyond the Ping-Pong table", 11-16.

${ }^{40}$ The contact person at the club has been the former Head of Communication, Ketty Calatayud.

${ }^{41}$ Priority has been given to analysing the journalistic discourse generated immediately following the visit of FC Barcelona to Israel and Palestine. Through an examination of the media repercussion of the event (a review of all the mainstream Spanish press coverage of the tour provided by FC Barcelona), the aim is to complement and contrast the information 
obtained from primary sources. The research has not extended to a systematic analysis of the media presence of FC Barcelona as a result of the club's visit to the Middle East.

${ }^{42}$ See Gil-Lafuente, "Marketing management in a socially complex club: Barcelona FC", 186207; Hamil, Walters, and Watson. "The model of governance at FC Barcelona", 475-504; Ginesta and Ordeix. "El fútbol profesional y su responsabilidad social corporativa en Cataluña (2006-2010)", 177-194.

${ }^{43}$ See Badia, Josep Suñol i Garriga.

${ }^{44}$ Ginesta and San Eugenio, "The Use of Football as a Country Branding Strategy", 8.

${ }^{45}$ For more information, see: http://foundation.fcbarcelona.com/, and Ginesta and Ordeix. "El fútbol profesional y su responsabilidad social corporativa en Cataluña (2006-2010)”, 177-194.

${ }^{46}$ Amongst other initiatives, on 29 November 2005 the club organised a benefit match for peace in the Middle East. The match was played in Barcelona between FC Barcelona and a 'Peace Team' made up of Israeli and Palestinian players. On 21 July 2011, Carles Villarubí, the vicepresident of the club, received Mahmoud Abbas, president of the Palestinian National Authority. On 13 January 2013, six young people from the Middle East (two Israelis, one Lebanese and three Palestinians) belonging to YaLa (Young Leaders Movement) attended a first-team training session at FC Barcelona's training ground at Sant Joan Despí (Barcelona). Source: F.C. Barcelona Press Office.

${ }^{47}$ Perearnau, F. 2013. "Segundo paso hacia el 'Partido por la Paz'”. Mundo Deportivo, August $4,8$.

${ }^{48}$ Perearnau, F. 2013. "Barça sin fronteras". Mundo Deportivo, August 4, 2.

${ }^{49}$ Ginesta and San Eugenio, "The Use of Football as a Country Branding Strategy", DOI: $10.1177 / 2167479513486886$.

${ }^{50}$ Correas, F. 2013. "10 milions pels amistosos de pretemporada". El 9 Esportiu, August 4, 6.

${ }^{51}$ Bassas, A. 2013. "Un design al Mur de les Lamentacions". Ara, August 5, 33.

${ }^{52}$ Cull, "Public Diplomacy: Taxonomies and Histories", 34

${ }^{53}$ This is a literal reproduction of the institutional declaration by Sandro Rosell, President of FC Barcelona, in Israel on 4 August 2013. Source: F.C. Barcelona Press Office.

${ }^{54}$ The organization of the match between FC Barcelona and a combined Palestinian-Israeli team came up against resistance from the PNA's policy of non-cooperation with the State of Israel. This policy is illustrated by the justification given by General Jibril Rajub, head of the Palestinian Football Association, to journalists covering this issue: 'We do not want to give the occupiers of our land an opportunity to carry out an activity in Palestine that appears normal and which hides the atrocities committed against our people' (Cabré, 2013: 36).

${ }^{55}$ Miguel, J. 2013. "El Barça convierte su 'clínic' en Palestina en un gesto por la paz". Sport, August 4, 14.

${ }^{56}$ Perearnau, F. 2013. "En casa de Mahmoud Abbas". Mundo Deportivo, August 4, 4.

${ }^{57}$ Domènech, J. 2013. "Barça de paz". El Periódico de Catalunya, August 5, 16.

${ }^{58}$ Usall, Futbol per la llibertat.

${ }^{59}$ Alba, A. 2013. "Huella en Tierra Santa". El Periódico de Catalunya, August 5, 16.

${ }^{60}$ Domènech, J. 2013. "Barça de paz". El Periódico de Catalunya, August 5, 16.

${ }^{61}$ Sugden, "Teaching and playing sport for conflict resolution and co-existence in Israel", 237238.

${ }^{62}$ Sugden, "Critical left-realism and sport interventions in divided societies", 268-269.

${ }^{63}$ Cull, "Public Diplomacy: Taxonomies and Histories", 31-54.

${ }^{64}$ See Rowe, "Sport and the Reproduction of the Global", 281-294.

${ }^{65}$ Ginesta and San Eugenio, "The Use of Football as a Country Branding Strategy", DOI: $10.1177 / 2167479513486886$.

${ }^{66}$ For more iformation see: http://fundacio.fcbarcelona.cat/projectes/detall/fitxa/futbol-net

${ }^{67}$ Xifra, "Soccer, civil religion, and public relations", 195.

${ }^{68}$ Capdevila, G. 2013. "Guerra i pau”. El 9 Esportiu, August 5, 3. 